\title{
Evidence that rising coastal seawater temperatures increase reproductive output of the invasive gastropod Crepidula fornicata
}

\author{
Alexandra Valdizan, Peter G. Beninger*, Priscilla Decottignies, Marianne Chantrel, \\ Bruno Cognie
}

Laboratoire de Biologie Marine, Faculté des Sciences et des Techniques, Université de Nantes, 2 rue de la Houssinière, Nantes 44322, France

\begin{abstract}
Although water temperature is thought to be an important factor in the proliferation of the invasive slipper limpet Crepidula fornicata along the northern European Atlantic coast, evidence for this proposition is scarce. We used quantitative histology to compare the reproductive dynamics over 2 temporally-separated sexual cycles (2000-2001 and 2006-2007) from the same C. fornicata population in Bourneuf Bay, France. Water temperature and chlorophyll (chl) $a$ data were also analyzed in relation to historical trends and to reproductive processes. Historical temperature data show a progressive warming trend, especially since 1995, when the slipper limpet problem began to be severe. Similarly, the incidence of high chl a peaks increased markedly from 1996 onwards. Significantly higher water temperatures and more chl a peaks were found for the 2006-2007 sampling period compared to 2000-2001, and corresponded to (1) an increase in duration of brood presence, most notably the appearance of broods earlier in the year, and (2) an increase in intensity of gametogenesis in 2006-2007. These results support the hypothesis that increased Northern European water temperatures enhance the reproductive success of C. fornicata, both through more favourable gametogenic/brooding temperatures and through enhanced phytoplankton availability.
\end{abstract}

KEY WORDS: Temperature $\cdot$ Warming $\cdot$ Proliferation $\cdot$ Chlorophyll $a \cdot$ Invader $\cdot$ Reproduction Resale or republication not permitted without written consent of the publisher

\section{INTRODUCTION}

The calyptraeid gastropod Crepidula fornicata has become a major invasive species along European Atlantic coasts, with a geographic range from Spain to Norway (Blanchard 1997, Davis \& Thompson 2000). Its proliferation has considerably impacted the shallow, soft and mixed-bottom habitats in which it is found (Le Pape et al. 2004, Arbach Leloup et al. 2008). The abundance of $C$. fornicata heavily modifies the nature and the structure of the habitat (through biodeposition production and shell accumulation) to the advantage of this species (Ehrhold et al.
1998). Furthermore, it creates competition for food and space with economically-important suspensionfeeders (oysters and scallops, e.g. Blanchard 1997, Beninger et al. 2007, Decottignies et al. 2007a,b) and disturbs both oyster farming and commercial bottom fisheries (additional cleaning operations before commercialisation of molluscs, drag clogging on productive epibenthic shellfish sites, e.g. Blanchard 1997, 2001, Soulas et al. 2000).

Along the Brittany coast of France, 60 yr after its introduction, Crepidula fornicata populations constitute a considerable, and increasing, biomass. High densities have been reported in several bays, using 
different techniques (e.g. side-scan sonar, submarine videos, quantitative samplings, mapping): $160000 \mathrm{t}$ in Mont Saint-Michel Bay (mean density: $267 \mathrm{t} \mathrm{km}^{-2}$, Blanchard \& Ehrhold 1999); $250000 \mathrm{t}$ in Saint-Brieuc (313 t km${ }^{-2}$, Hamon \& Blanchard 1994, Blanchard et al. 2001); $128000 \mathrm{t}$ in Brest $\left(826 \mathrm{t} \mathrm{km}^{-2}\right.$, Chauvaud 1998); $51000 \mathrm{t}$ in Bourgneuf Bay $\left(146 \mathrm{t} \mathrm{km}^{-2}\right.$; Barillé \& Barillé 2003, Sauriau et al. 2006). Despite several strategies applied to control its biomass (Blanchard \& Thomas 1998, Soulas et al. 2000), slipper limpet proliferation appears to be continuing unabated (Sauriau et al. 1998, Blanchard \& Ehrhold 1999, Blanchard 2009, Valdizan et al. 2009).

Proliferation of an invasive species depends at least in part on its successful reproduction; it is therefore important to investigate the reproductive dynamics of Crepidula fornicata in relation to environmental variables which most impact this process. Although the complex reproductive dynamics of C. fornicata has recently been documented (Beninger et al. $2010 a, b)$, information on the eventual changes to such dynamics over recent years obviously requires at least 2 recent data sets, separated by an appreciable time interval. In the present study, therefore, an additional, previously unexploited data set from the same population of the Bourgneuf Bay (France) in 2000-2001 was analyzed in the same manner as in 2006-2007 (Beninger et al. 2010a,b), providing 2 data sets separated by a 6 -yr time interval.

Warming of water temperature may increase the success of invasive species by facilitating their geographic spread and by promoting more successful reproduction, larval development, and juvenile recruitment (Stachowicz et al. 2002, Thieltges et al. 2004, Diederich et al. 2005, Cognie et al. 2006, Dutertre et al. 2010). A pronounced positive effect of water warming on the reproduction of another invasive species, Crassostrea gigas (feral oysters), has previously been documented (Cognie et al. 2006, Dutertre et al. 2010) for Bourgneuf Bay. It thus seems logical to investigate the same possibility for Crepidula fornicata. We therefore investigated the relationship between temperature and the reproductive dynamics of a $C$. fornicata population in Bourgneuf Bay, a midlatitudinal point in the European $C$. fornicata distribution, at 2 chronologically-spaced points in recent time: 2000-2001 and 2006-2007.

\section{MATERIALS AND METHODS}

\section{Specimen sampling, histological preparation and reproductive dynamics analysis}

Crepidula fornicata specimens were hand-collected in the intertidal of Bourgneuf Bay (French Atlantic coast, $46-47^{\circ} \mathrm{N}, 1-2^{\circ} \mathrm{W}$; Fig. 1), a slipper limpetinvaded ecosystem located south of the Loire estuary (Barillé \& Barillé 2003, Valdizan et al. 2009, Beninger et al. 2010a,b). A minimum of 50 slipper limpets were sampled once or twice per month from late June 2000 to late June 2001, and twice per month from late March 2006 to September 2007. Stacks of $\sim 4$ to 5 adult individuals were selected in order to ensure equal representation of males and females (the bottom 2 generally female, the rest male in this protandric species; only 2 transitional individuals were observed, the sex switch apparently being very rapid in C. fornicata). The topological and quantitative histological protocol followed that of Beninger et al. $(2010 \mathrm{a}, \mathrm{b})$. Stereological methods were used to determine volume fractions of different tissue types in the histological sections (Weibel et al. 1966, Briarty 1975, Morvan \& Ansell 1988, Pazos et al. 1996, Mayhew 2000, Beninger et al. 2001). For each section of the ovary, stereological counts were performed on 3 haphazardly-chosen areas using a $10 \times 10$ point matrix on the microscope screen at $100 \times$, as described in Dutertre et al. (2009). In females, 6 tissue categories were counted: developing oocytes, mature oocytes, oocytes undergoing atresia, lysed oocytes, unoccupied tubule space, and inter-tubular space. Since male gonad tissue is scarce, irregular and small in the

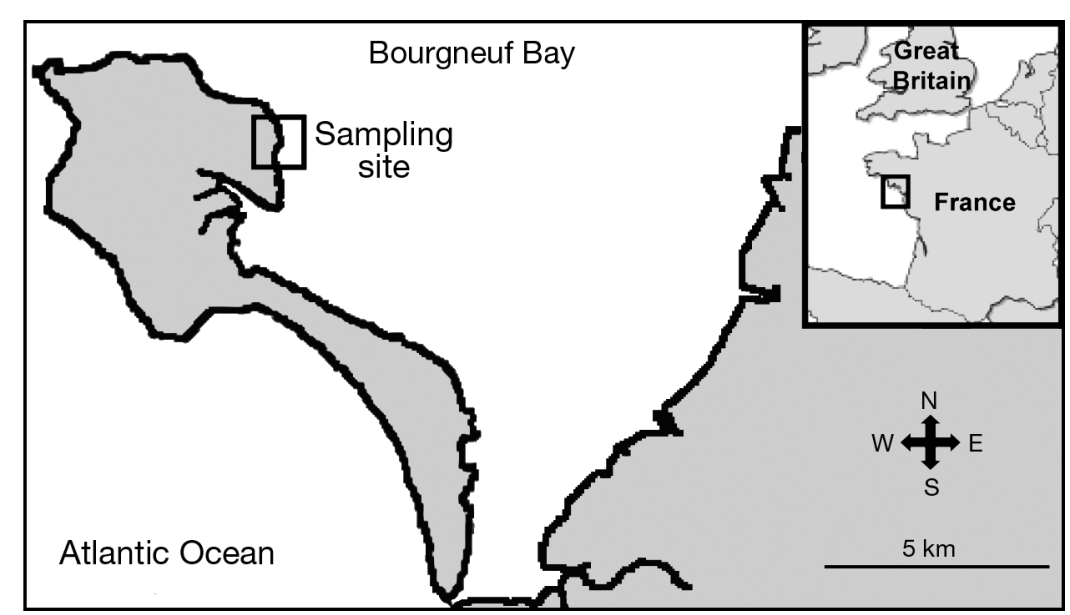

Fig. 1. Crepidula fornicata. Study area and sampling site of slipper limpet C. fornicata in Bourgneuf Bay 
large visceral mass (Gould 1917), counts were performed using a $20 \times 20$ point matrix at $200 \times$ on 3 haphazardly-chosen areas containing visible tubules. In males, 5 categories of gonad tissue were counted: developing gametes, immature spermatozoa, mature spermatozoa, residual spermatozoa, unoccupied lumen, and inter-tubular space in males. In male and female samples, for each of the 3 randomly-chosen areas, 3 counts were performed and the means were calculated (with $95 \%$ confidence intervals) and plotted.

Samples from December 2000 (males and females) and from late June 2001 (females only) could not be counted due to gamete leakage from tubules close to the plane of biopsy (the only tubules visible at this location in the gonad in these months). For each sample, the presence or absence of incubated egg capsules (brooding) was noted and used to assist in the interpretation of reproductive events.

\section{Water temperature over the sampling periods, historical water temperature and chlorophyll (chl) a data}

The REPHY (REseau PHYtoplancton, www.ifremer. fr/lerlr/surveillance/rephy.htm) is a long-term survey of French coastal waters conducted by the Institut Français de Recherche pour l'Exploitation de la Mer (IFREMER), since 1984. Bimonthly measurements of temperature and chl a $\left(\mu \mathrm{g}^{-1}\right)$ were extracted from the REPHY Quadrige database for the 2 sampling periods in Bourgneuf Bay.

Water temperatures (WT) prior to 1984 were calculated between January 1970 and December 2007 using the following regression (Haure \& Baud 1995):

$$
\mathrm{WT}=0.8703 \times \mathrm{AT}+0.036 \mathrm{TC}-0.0969
$$

Atmospheric temperatures (AT) were obtained from the Météo-France Climathèque database (Noirmoutier Station; $47^{\circ} 00^{\prime} 18^{\prime \prime} \mathrm{N}, 2^{\circ} 15^{\prime} 24^{\prime \prime} \mathrm{W}$ ), and tidal coefficients (TC) using the Marées dans le Monde v2.02 software. Chl a data for Bourgneuf Bay were extracted from the REPHY Quadrige database, from 1996 to 2007 . No chl a values were available prior to 1996.

\section{Data analysis}

SigmaStat 2.0 (Jandel Scientific) was used to check the normality and homoscedasticity of data distributions and subsequent statistical analyses. Annual means of temperature $(T)$ and chl a were compared between 2000-2001 and 2006-2007 by, respectively, Student's $t$-test $\left(T\left[{ }^{\circ} \mathrm{C}\right.\right.$ ] data normally distributed and homogeneous variances) and Mann-Whitney test (chl a data non-normally distributed and heterogeneous variances). As stereological counts, historical water temperatures and chl a data were non-normally distributed and characterized by heterogeneous variances; non-parametric (Kruskall-Wallis) ANOVAs were performed. ANOVAs were all followed by multiple-comparison Tukey's test to detect significant differences in means $(p<0.05)$ of gamete volume fractions between 2000-2001 and 2006-2007, and of temperature and chl a over time. A non-parametric linear regression was used to detect a possible relationship between water temperatures and time since 1970 .

\section{RESULTS}

\section{Gametogenic cycle stability of Crepidula fornicata, 2000-2001 versus 2006-2007}

\section{Males}

The 2000-2001 male sexual cycle presents the same general profile as previously described for 2006-2007 (Beninger et al. 2010a,b): (1) a period of high spermatozoan production in spring-summer (Fig. 2), characterized by the presence of all stages of spermatogenesis from the basal syncytium to the gonad tubule lumen; (2) a period of spermatozoan atresia in autumn-winter (Fig. 2), characterised by the presence of a large proportion of degenerating gametes in the tubule lumen.

As observed in Beninger et al. $(2010 \mathrm{a}, \mathrm{b})$ for 2006-2007, the mean percentage of developing gametes (spermatocytes and immature spermatozoa) in 2000-2001 was significantly greater during the high spermatozoan production periods than during the period of atresia (Fig. 2; Kruskall-Wallis test: $F=2.43, \mathrm{n}=14$, df $=13, \mathrm{p}<0.001)$. Nevertheless, throughout the sampling interval, the developing gamete proportions were significantly lower for 2000-2001 compared to 2006-2007 (Fig. 2; $F=$ $2.004, \mathrm{n}=27$, $\mathrm{df}=26$. $\mathrm{p}<0.001$ ), with mean percentages $( \pm 95 \% \mathrm{CI})$ of $15.7 \%( \pm 2.4)$ in $2000-2001$, and $26.1 \%( \pm 2.2)$ in 2006-2007 (Fig. 2). Despite the low spermatogenesis observed for 2000-2001, the mature spermatozoa proportions inside the tubules during spermatozoan production periods were highly similar to those found for 2006-2007 (Fig. 2), 
with mean spermatozoan percentages $( \pm 95 \% \mathrm{CI})$ of $16.9 \%( \pm 5.5)$ for $2000-2001$ and $14.4 \%( \pm 2.2)$ for 2006-2007.

Females

The 2000-2001 female sexual cycle presents the same general profile as previously described for 2006-2007 (Beninger et al. 2010a,b): (1) a period of oocyte atresia in spring-summer (Fig. 3), characterized by the presence of oocytes slowly degenerating and sometimes totally lysed inside the tubules; (2) a period of oocyte maturation in autumn-winter (Fig. 3), characterized by the presence of large mature oocytes filled with vitellin droplets in the gonad tubules.

Beninger et al. $(2010 \mathrm{a}, \mathrm{b})$ observed that female gamete production followed a clear annual cycle in 2006-2007, with developing oocyte percentages

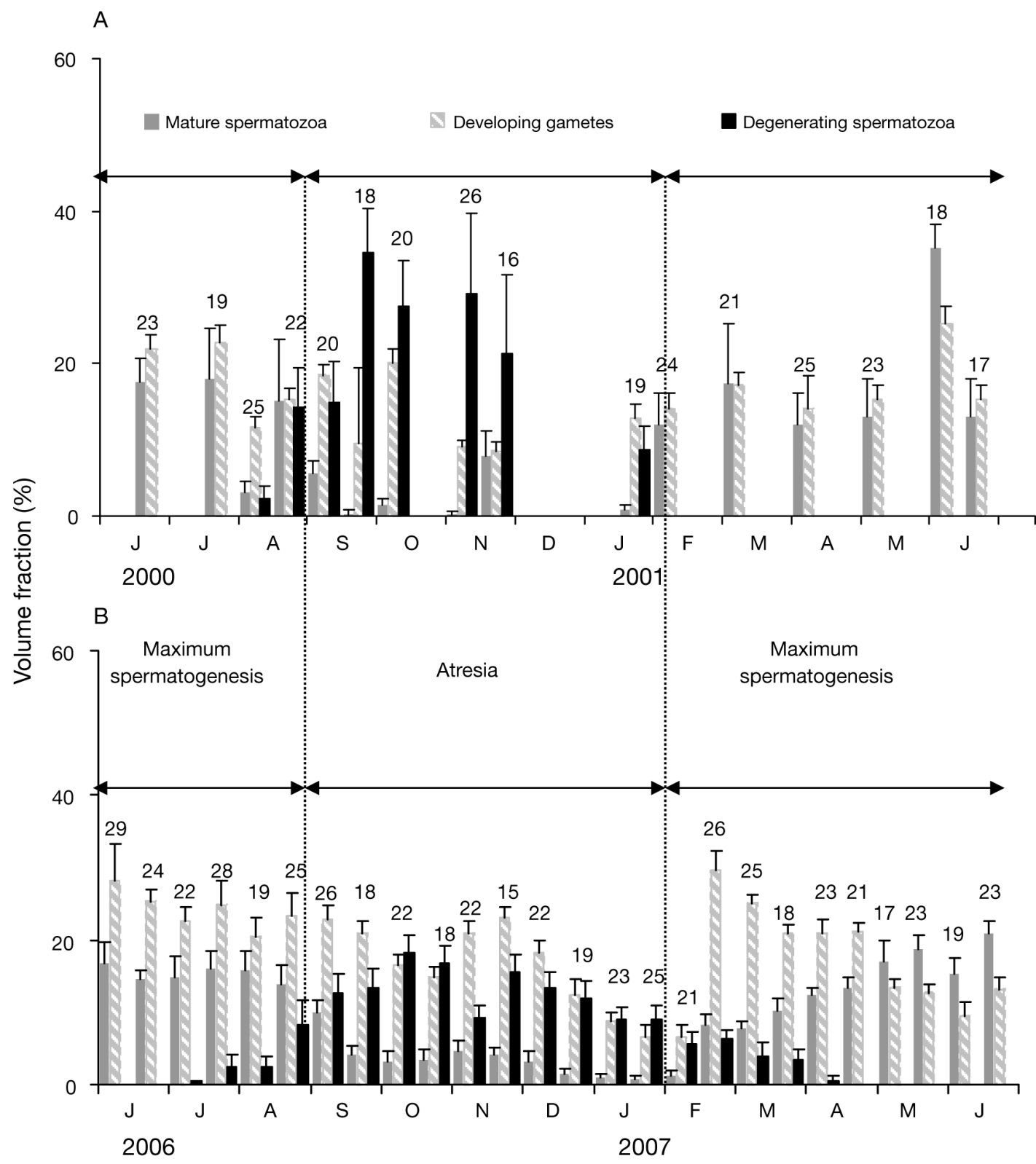

Fig. 2. Crepidula fornicata. Stereological results for C. fornicata testis. Volume fractions of mature spermatozoa, developing gametes (spermatocytes and immature spermatozoa) and degenerating spermatozoa in the testis, June 2000-2001 (1-2 samples $\mathrm{mo}^{-1}$ ), and June 2006-2007 (2 samples $\mathrm{mo}^{-1}$ ), means $\pm 95 \%$ CI. Dotted lines: common phases of reproductive cycle in (A) 2000-2001 and (B) 2006-2007. Data unavailable in December 2000 due to gamete leakage from tubules close to the plane of biopsy (the only tubules visible at this location in the gonad in these months). Sample sizes: above each CI 
(mean $\pm 95 \% \mathrm{CI}$ ) significantly greater during brooding periods $(13.5 \pm 2 \%)$ than during the non-brooding period $(10.2 \pm 2.6 \%)$ (Fig. $3 ; F=2.96, \mathrm{n}=13$, df $=$
$12, \mathrm{p}<0.001)$. In contrast, the percentages of developing oocytes for 2000-2001 were much lower, with mean developing oocyte percentages as little as 4

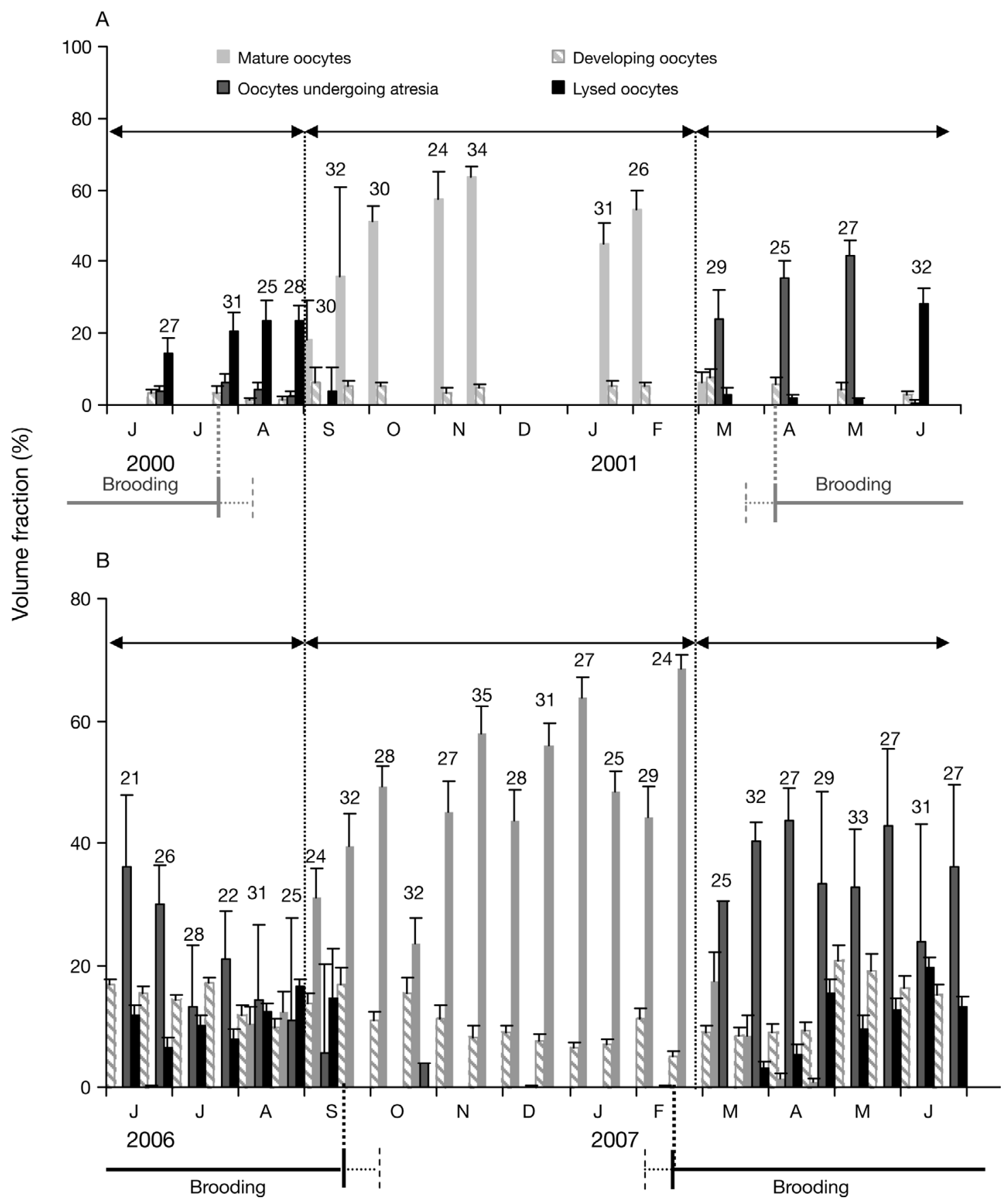

Fig. 3. Crepidula fornicata. Stereological results for C. fornicata ovary. Volume fractions of mature oocytes, developing oocytes, atresic oocytes and lysed oocytes in the ovary, (A) June 2000-2001 (1 or 2 samples mo $^{-1}$ ) and (B) June $2006-2007$ $\left(2\right.$ samples $\left.\mathrm{mo}^{-1}\right)$, means $\pm 95 \%$ CI. Dotted lines: common phases of the reproductive cycle in 2000-2001 and 2006-2007. Data unavailable in December 2000 and in late June 2001 (only for females) due to gamete leakage from tubules close to the plane of biopsy (the only tubules visible at this location in the gonad in these months). Sample sizes: above each CI. Periods of brooding for 2000-2001 and 2006-2007 (Valdizan et al. 2009) are indicated below the graph — solid lines: all dates at which broods were observed, dotted portions: maximum possible brooding period length (end of brooding season) and the earliest possible onset of brooding (see 'Results: females') 


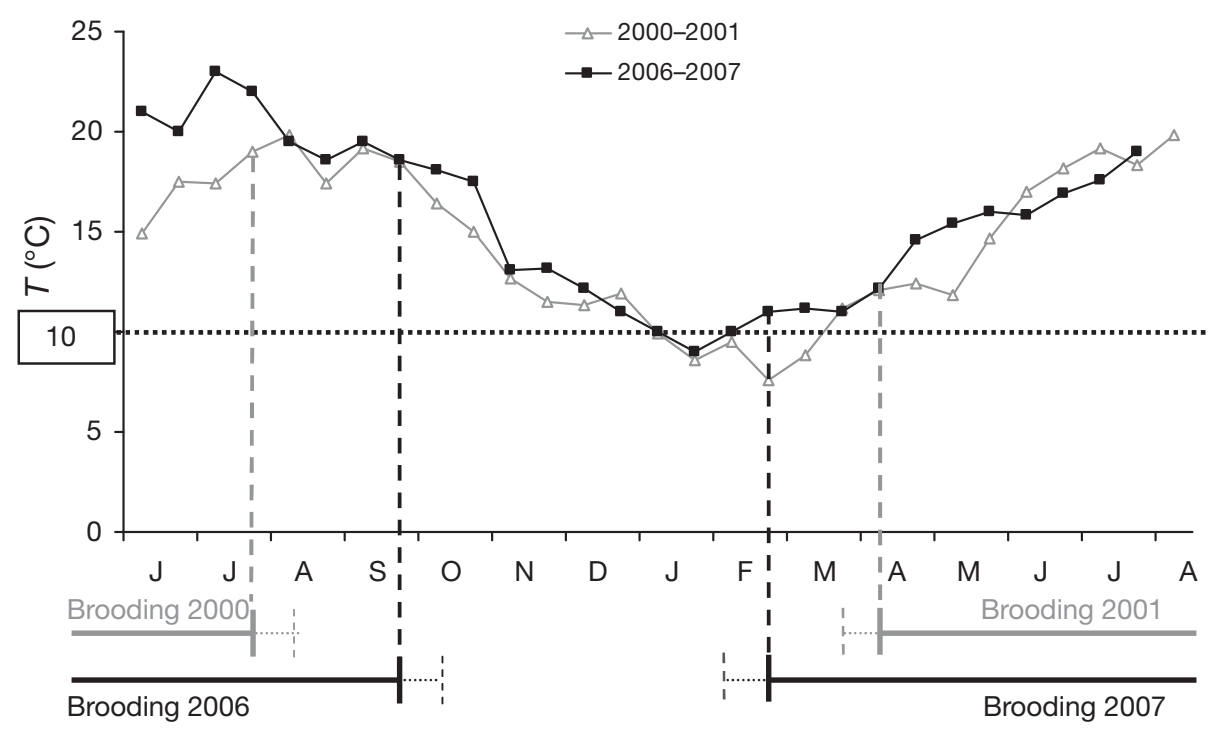

Fig. 4. Crepidula fornicata. Water temperatures (T) for both sampling periods: June 2000-early August 2001, and June 2006-early August 2007. Horizontal dotted line: minimal threshold required to activate the brooding process $\left(10^{\circ} \mathrm{C}\right)$. Vertical dashed line: correspondence between this threshold and the beginning of brood incubations. Brooding periods are indicated below the graph (description see Fig. 3)

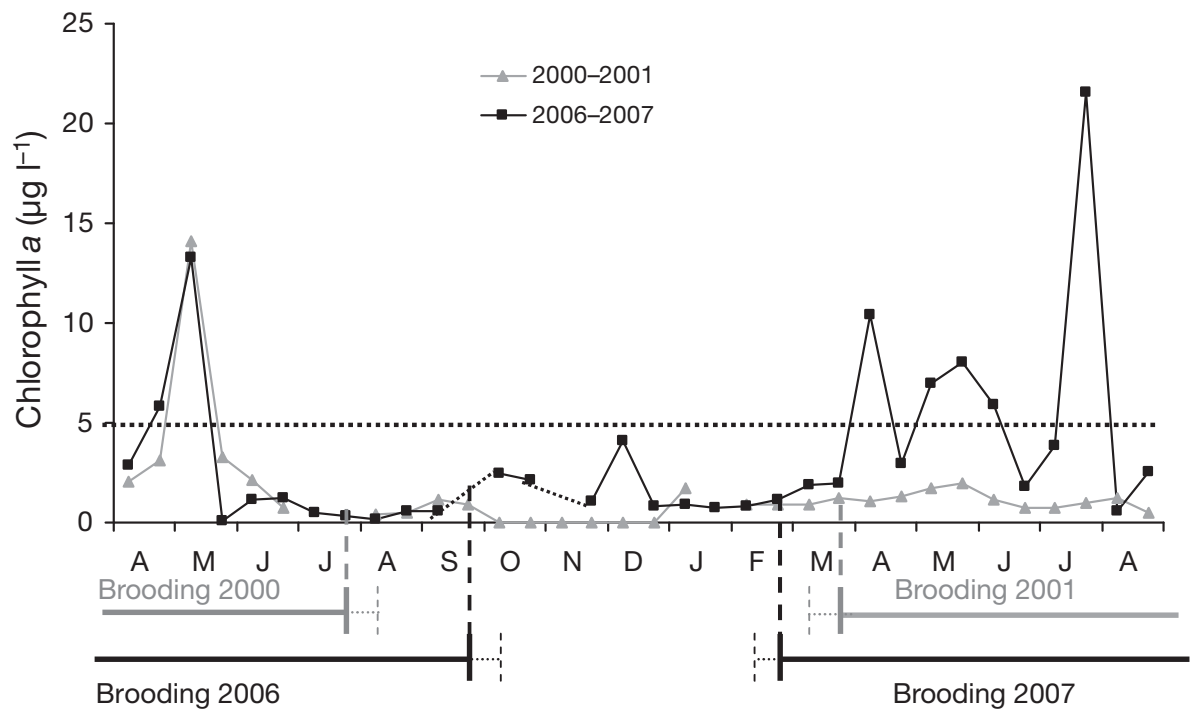

Fig. 5. Chl a concentration from April 2000-August 2001, and April 2006-August 2007 (2006-2007 brooding periods data from Valdizan et al. 2009). Data for late September and November 2006 not available. Horizontal dotted line: concentrations clearly separating low $\left(<5 \mu \mathrm{g} \mathrm{l}^{-1}\right)$ from elevated $\left(>5 \mu \mathrm{g} \mathrm{l}^{-1}\right)$ chl a values. Brooding periods are indicated below the graph (description see Fig. 3)

times less than in 2006-2007 $(F=2.39, \mathrm{n}=25, \mathrm{df}=24$, $\mathrm{p}<0.001)$; no distinct variations of the developing oocyte proportions throughout the sampling period were observed (Fig. 3).

As was observed for the male gametes, despite the low oogenesis found for 2000-2001, the mature oocyte percentages observed during the oocyte maturation period were similar to those found in the same period for 2006-2007, with mean percentages $( \pm 95 \%$ CI) of $47.1 \%( \pm 10.6)$ for $2000-2001$ and $47.5 \%( \pm 7.5)$ for 2006-2007. Multiple minor decreases in the mature oocyte percentages were observed for both sampling periods during the nonbrooding period, indicating that the bulk of the 
mature oocytes had been transferred to the uterus during the non-brooding period (Fig. 3; Beninger et al. 2010a,b).

Periods of brood presence were markedly shorter in 2000-2001 (late March to late July) than in 2006-2007 (mid-February to late October; Figs. 3, 4 \& 5). As brood presence was recorded every $\sim 2 \mathrm{wk}$, it was not possible to determine the exact date of initiation or termination of brooding. Figs. 3, 4 \& 5 therefore show the dates at which broods were actually observed, and dotted lines indicate the earliest possible date of brooding based on the observation of the previous sampling date, and the latest date of brood presence based on the observation of the following observation date.

\section{Environmental variations}

Historical variations in water temperature and chl a

Calculated historical annual and warmest-month mean water temperatures are presented for Bourgneuf Bay from 1970 to 2007 (Fig. 6A). Also shown for each of the years during this time period is the date from which the water temperature threshold necessary to activate brooding in Crepidula fornicata was attained $\left(10^{\circ} \mathrm{C}\right.$; Werner 1948, Chipperfield 1951, Thieltges et al. 2004, Richard et al. 2006) (Fig. 6B).

Fig. 6A shows a significant warming of annual mean water temperatures $\left(\mathrm{r}^{2}=0.639, \mathrm{p}<0.001\right)$ and of warmest month water temperatures from 1970 to
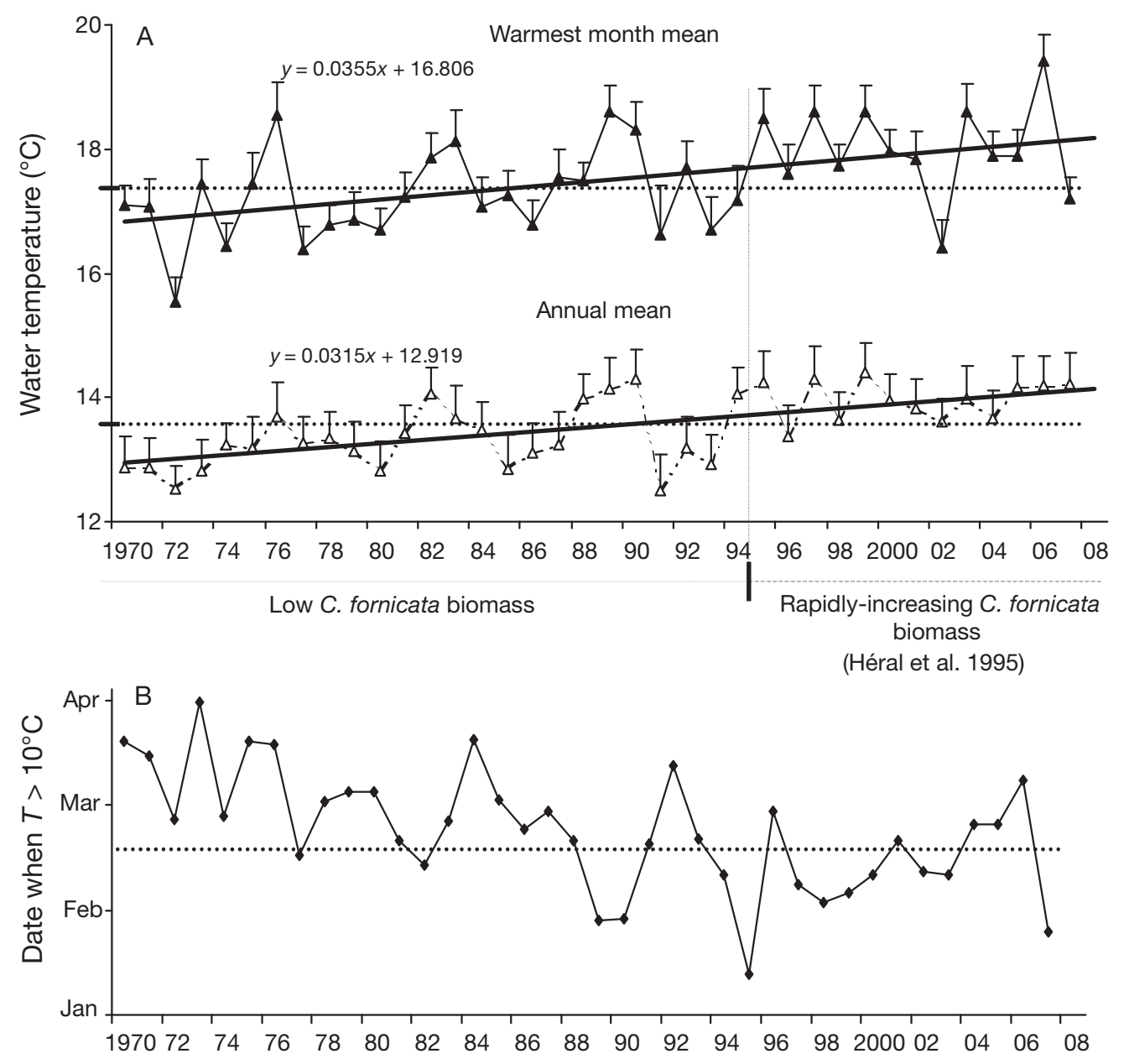

Fig. 6. Crepidula fornicata. Historical variations in water temperature in Bourgneuf Bay since the proliferation of $C$. fornicata in the 1970s (Météo-France, Climathèque data base, Noirmoutier). (A) Annual mean and warmest month mean. Dotted lines: temperatures that clearly separate earlier and more recent values. Continuous lines: both linear regressions, equations are presented. (B) Date when water temperatures $(T)$ exceed the $10^{\circ} \mathrm{C}$ threshold necessary to activate brooding. Dotted line: midpoint of the 4 mo interval 


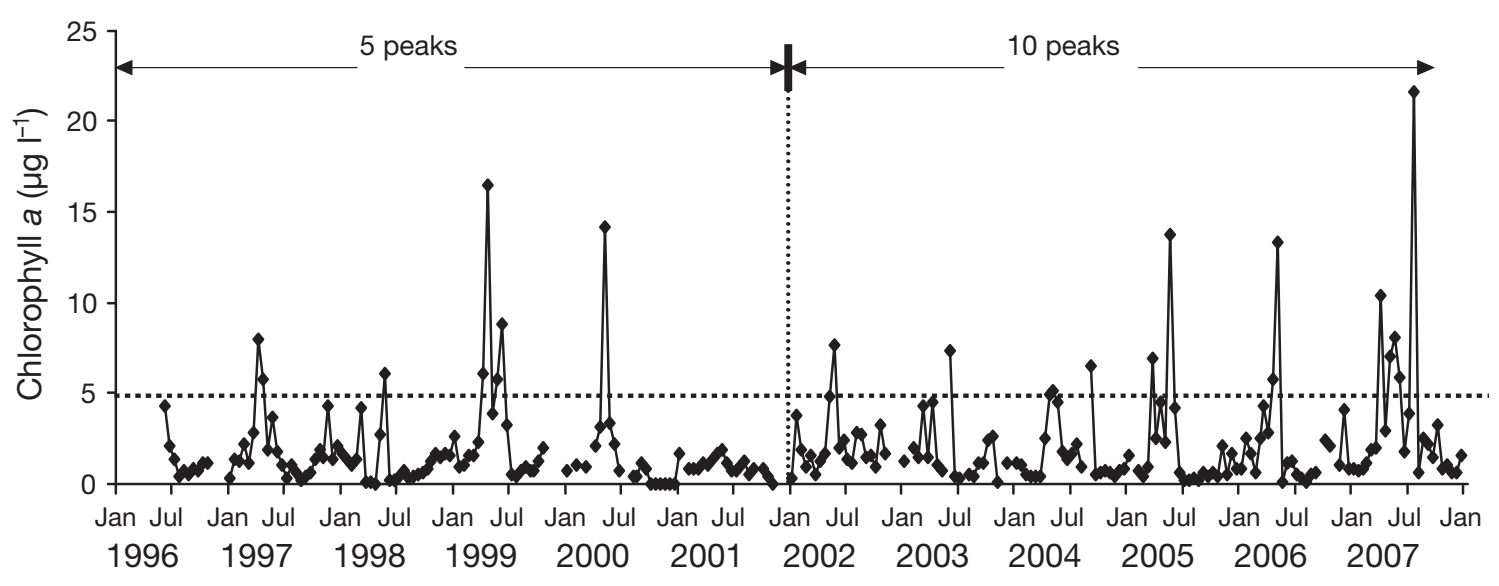

Fig. 7. Historical variations in chl a in Bourgneuf Bay since the accelerating increase in slipper limpet biomass, $1996-2007$. Horizontal dotted line: concentrations clearly separating low $\left(<5 \mu \mathrm{g} \mathrm{l}^{-1}\right)$ from elevated $\left(>5 \mu \mathrm{g} \mathrm{l^{-1 }}\right)$ chl a values. In 6 yr period: 10 elevated values in 2002-2007 vs. 5 elevated values in 1996-2001

$2007\left(\mathrm{r}^{2}=0.485, \mathrm{p}<0.001\right)$. Indeed, in the period 1970-1994, only 8/26 (30.8\%) of the annual mean water temperatures were $>13.5^{\circ} \mathrm{C}$, whereas from 1995 to $2007,12 / 13$ (92\%) of the annual mean water temperatures were above this value. Similarly, in 1970-1994, only 8/26 (30.8\%) of the warmest month temperatures were $>17.5^{\circ} \mathrm{C}$, while in $1995-2007$, $11 / 13(84 \%)$ were above this value.

Fig. 6B shows that in 1970-1985, the period at which water temperature attained the $10^{\circ} \mathrm{C}$ brooding activation threshold was in the month of March in only 6/16 years (37\%), whereas in 1986-2008, this temperature was attained in the month of March or February in 19/22 years (86\%).

Although there was a statistically-significant increase of the chl a concentrations from 1996 to 2007 ( $F$ $=2.06, \mathrm{n}=12, \mathrm{df}=11, \mathrm{p}=0.024$ ), examination of the number of extreme peaks shows the progression of this episodic phenomenon more clearly (Fig. 7). Indeed, in 1996-2001, only $5.55 \%$ of the chl a concentrations were $>5 \mathrm{\mu g} \mathrm{l}^{-1}$, whereas in 2002-2007, $12.5 \%$ of the chl a concentrations were above this value. Furthermore, in the 6 years of 2002-2007, there were 10 elevated values $\left(>5 \mu \mathrm{g} \mathrm{l}^{-1}\right)$ versus 5 elevated values in the 6 years of 1996-2001.

Influence of temperature and chl a on the reproductive cycle of Crepidula fornicata

Less favourable temperature conditions were found for 2000-2001, coinciding with the low gametogenesis observed for these dates, compared to 2006-2007 gametogenesis (see 'Results: male' and 'Results: female'). Temperatures (Fig. 4) for this period were significantly lower than for 2006-2007 ( $t$-test: $t=-2.3$, $\mathrm{n}=29$, df $=28, \mathrm{p}=0.029)$, with respective annual means $( \pm 95 \% \mathrm{CI})$ of $14.5( \pm 1.4)$ and $15.7^{\circ} \mathrm{C}( \pm 1.5)$.

Both in 2000-2001 and in 2006-2007, the initiation of Crepidula fornicata brooding coincided precisely with fluctuations of this environmental variable (Fig. 4). First appearance of incubated broods in 2001 and 2007 began when water temperature reached the minimum threshold of $10^{\circ} \mathrm{C}$ (Fig. 4).

Chl a values were much higher in 2007 compared to 2001 (Mann-Whitney test: $U=8.2, \mathrm{n}=45$, df $=44$, $\mathrm{p}=0.028$; Fig. 5). As was the case for the temperature data, this corresponded to a greater intensity of gametogenesis in 2006-2007 (see 'Results: male' and 'Results: female'). Slightly higher values of chl a were observed in early spring $2007\left(0.79-1.97 \mu \mathrm{g} \mathrm{l}^{-1}\right)$ compared to $2001\left(0.89-1.19 \mu \mathrm{g} \mathrm{l}^{-1}\right)$, at the same time as water temperature exceeded the $10^{\circ} \mathrm{C}$ threshold, and coinciding with the 1-mo earlier initiation of brooding in 2007. Furthermore, more abundant food was available in 2007, with 3 peaks of chl a above a concentration of $5 \mu \mathrm{g} \mathrm{l}^{-1}$ observed from the end of spring until summer (April, June, late July) whereas no chl a values $>5 \mu \mathrm{g} \mathrm{l^{-1 }}$ were observed during this period in 2001.

\section{DISCUSSION}

\section{Reproductive cycles}

The results of the present study demonstrate that although the same basic chronological pattern of reproductive activity was observed in both 20002001 and 2006-2007 in the Bourgneuf Bay Crepidula fornicata population, important differences in dura- 
tion and intensity of gametogenesis and oviposition are evident. These differences are (1) earlier initiation, and possibly later termination of brooding period in 2006-2007 compared to 2000-2001, and (2) greater intensity of reproductive activity in 20062007 compared to 2000-2001.

\section{Extended periods of brood presence}

The period of brood presence was longer in 2006-2007 than in 2000-2001; consequently, the release of larvae to the water column and subsequent benthic recruitment was possible for a much longer period in 2006-2007. Given the spatial and trophic competition between cultured/feral cupped oysters Crassostrea gigas and Crepidula fornicata in this bay and elsewhere along the European coast (Blanchard 1997, Barillé et al. 2006, Beninger et al. 2007, Decottignies et al. 2007a,b, Blanchard et al. 2008), this extended brooding period could be particularly important. Normal C. gigas spawning in Bourgneuf Bay occurs from May to July (Dutertre et al. 2009, 2010), so the appearance of $C$. fornicata larvae as early as February would permit the benthic recruitment of this species well in advance of C. gigas (which spawned in May of both 2005 and 2006, Dutertre et al. 2009), and may be a factor in the recent proliferation of $C$. fornicata in habitats where it competes with C. gigas.

The extension of brooding to October in 2006 compared to July in 2000, also underscores the increased length of brooding period in 2006-2007. It also enables benthic recruitment to continue after the heavy mortalities that typically occur in naturallyrecruiting Crassostrea gigas populations (Mackin 1961, His \& Robert 1985, His \& Seaman 1992, Dégremont et al. 2007, Dutertre et al. 2010), again enhancing the competitive position of Crepidula fornicata.

\section{Greater intensity of reproductive activity}

The various phases of Crepidula fornicata gametogenesis were markedly more intense in 2006-2007, resulting in a gamete production (for males and females) twice as high compared to 2000-2001. It may be argued that the gamete residence time in the tubules differed between the years; however, the breeding period was initiated earlier in 2006-2007 than in 2000-2001, so if a shorter gamete residence time did exist for one of the 2 time periods, it would probably be for 2006-2007, and not 2000-2001. The fact that more gametes were observed in the tubules in 2006-2007 belies this possibility, so our interpretation appears valid.

The increased fecundity in 2006-2007 probably translated to greater larval numbers and benthic recruitment than compared to 2000-2001. The combined effect of both an extended brooding season and increased propagule numbers may be expected to accentuate the proliferation of Crepidula fornicata in Bourgneuf Bay, and by the same token, provide a competitive advantage to this species with respect to the co-occurring Crassostrea gigas.

It has been suggested that control of molluscan recruit numbers is essentially top-down and independent of recruit input (Menge 2000, Severns 2007). However, several factors may attenuate this paradigm, especially in the case of invasive Crepidula fornicata. First, there is the possibility of swamping potential predators with recruiting animals (e.g. Hollebone \& Hay 2007), such that many of the excess recruits will survive and hence contribute to proliferation. Second, the availability of predators may be a determining factor. Previous mudflat studies have implicated mainly decapod crustaceans in predation on juveniles (and these were juvenile bivalves; Beukema et al. 1998, Seitz \& Lipcius 2001), whereas at our study site, no evidence of such predators was observed (no live individuals, and only very few empty carapaces). The alternative mudflat predators, shorebirds, may exert relatively low predation pressure due to issues of timing and duration (migration stopovers), and, something that may greatly influence bird predation on juveniles but is often overlooked: international differences in hunting regulations. Shorebirds are hunted in France, producing very skittish assemblages on the mudflats, and may spend much less time foraging than they do in countries where hunting is forbidden.

Finally, there is the particular case of Crepidula fornicata. Some studies have suggested that the indigenous submarine potential predators do not seem to have learned either (1) that $C$. fornicata is a potential food source, or (2) how to prey upon it (Coum 1979, Blanchard 1995, 1997, Sax \& Brown 2000); thus, top-down control for this particular species in the invaded habitat seems unlikely.

\section{Influence of water temperature and chl $a$ on reproductive cycle}

Temperature is considered the single most important factor in controlling reproduction in opisthobranch gastropods (Hadfield \& Switzer-Dunlap 1984). 
The higher water temperatures and chl a values at the study site in 2006-2007 compared to 2000-2001 coincided with a greater intensity of gametogenesis in Crepidula fornicata. In addition, for both sampling periods, C. fornicata brooding started when the $10^{\circ} \mathrm{C}$ threshold was reached, as has been observed in previous studies (Werner 1948, Chipperfield 1951, Thieltges et al. 2004, Richard et al. 2006). This value probably reflects the minimal water temperature required for larval survival and development in the water column (Estrella Klinzing \& Pechenik 2000, Zhao et al. 2003). The warmer water temperatures in late winter-early spring of 2007, compared to 2001, allowed this threshold to be attained 1 mo earlier in 2007.

The historical chl a data show that elevated values are much more frequent after 2001 than before that year. This time frame corresponds to the most elevated mean annual temperature values, suggesting that elevated chl a values are related to elevated temperature values. While availability of food is undoubtedly important to reproduction (Hadfield \& Switzer-Dunlap 1984), the results of the present study show that the shift in initiation of brooding could not be imputed to the chl a values alone, since even higher values were found at periods prior to initiation of brooding. Water temperature therefore appears to be a determining factor in the initiation of brooding in Crepidula fornicata, while the intensity of gametogenesis may be related to food availability.

Although the initiation of oviposition appears to be dependant on water temperature, this variable does not appear to affect the termination of oviposition, which happened in late July 2000 compared to late October in 2006. Termination of incubation is therefore probably controlled by the availability of fertilized oocytes and, ultimately, of energy stores acquired from feeding.

The highly significant water temperature elevation between 1970 and 2007, and especially 1995 to 2007 (ter Hofstede et al. 2010, present study) coincides with the accelerating increase in slipper limpet presence over the same period (Héral et al. 1995). This temperature increase appears to have allowed the activation of brooding earlier in the season, especially after 1989 , when the $10^{\circ} \mathrm{C}$ brooding activation threshold was attained 1 to 3 mo earlier than before 1989. As noted previously (Beninger et al. 2010a,b), earlier brooding would allow Crepidula fornicata larvae to recruit much earlier than an important competitor in this bay, Crassostrea gigas. The C. fornicata larvae might thus suffer reduced mortality prior to benthic recruitment, and as juveniles, enjoy a com- petitive advantage over the later-recruiting oysters. Previous studies have identified trophic competition between the larvae of these 2 species (Blanchard et al. 2008), and our work in progress indicates that the competition for food resources in the adults of these 2 species (Decottignies et al. 2007a,b) is mirrored in the juvenile stages (Decottignies et al. unpubl. data).

Global warming is expected to continue for decades in the mid- and high latitudes of the Northern hemisphere (Schneider 2001, Hawkins et al. 2003), so it is likely that this warming will enhance the reproductive success of Crepidula fornicata in Bourgneuf Bay, and probably over its European range, in the years to come. Indeed, on southern coasts of Chile where water temperatures are already always above the $10^{\circ} \mathrm{C}$ threshold (Velasco \& Navarro 2005), C. fecunda, which has the same reproductive and developmental characteristics as $C$. fornicata, appears to brood almost year-round (Chaparro et al. 2005). Furthermore, the warming of coastal waters can enhance invasions by permitting the colonization of invasive species previously restricted to lower latitudes (Carlton 2000). In the Wadden Sea, Northern Europe, the population of C. fornicata, once poorly established, has recently increased contemporaneously with coastal water temperatures and the decrease in winter severity (Thieltges et al. 2004, Nehls et al. 2006). Warming coastal waters may also provide increased pulses of particulate organic matter, as observed in the present study, allowing the assimilated energy to be directed toward increased reproduction. Invasive animal species are more likely to be generalists than specialists, indirectly facilitating adaptation to new climates (Rejmánek \& Richardson 1996). Indeed, C. fornicata shows many generalist characteristics: a pelagic larval stage that enables dispersion and colonization of new habitats (Blanchard 1997, Collin 2003, Dupont et al. 2006), a large tolerance to a wide range of environmental variables (e.g. temperature, salinity, turbidity, substrates; Coum 1979); and generalist suspension-feeding larval and adult stages able to thrive under many different dietary conditions (Barillé et al. 2006, Beninger et al. 2007, Decottignies et al. 2007a,b, Blanchard et al. 2008). Global warming of coastal water temperatures will probably favour $C$. fornicata and its attendant ecological impacts in Bourgneuf Bay and all along the Atlantic European coasts, including competitive interactions with native species (e.g. oysters, mussels, scallops), ecosystem effects (e.g. modification of the nature and structure of the bottom) and economic effects (e.g. shellfish culture and dredge fisheries; Hellmann et al. 2008). 
Furthermore, global warming could work together with other stressors (e.g. habitat alteration, pollution; Rogers \& McCarty 2000) to reduce populations of endemic species, while increasing populations of $C$. fornicata, already abundant in Bourgneuf Bay (Barillé \& Barillé 2003, Sauriau et al. 2006) and many other European coastal habitats (Hamon \& Blanchard 1994, Blanchard \& Ehrhold 1999, Richard et al. 2006, FitzGerald 2007).

\section{Strength of data}

Data from 2 time intervals were reported in the present study. We therefore compare 2 sample sets, 2000-2001 and 2006-2007, with 50 data points for each month of each period. Furthermore, the twopronged approach used here reinforces the strength of the data: (1) We are unaware of any other marine gastropod studies that have looked at the stability of reproductive cycles over such large time intervals. We therefore believe the data presented is the most convincing to date, allowing us to conclude that reproduction has been positively affected over the time interval. (2) With respect to concluding that the changes in reproductive intensity, precocity, and duration were probably due to temperature and chl $a$ effects, we use the proven minimum threshold temperature to initiate brooding (Werner 1948, Chipperfield 1951, Thieltges et al. 2004, Richard et al. 2006), field-validated in the 2001 and 2007 early spring periods, and historical temperature data, to show that early initiation of brooding has been possible since 1989, and that this effectively corresponds to the increasing proliferation of Crepidula fornicata in Bourgneuf Bay. We believe this argument substantial enough to at least underscore the relationship and constitute evidence for a temperature effect. Given the total lack of any similar data for any other location, this study should serve as a starting point for further investigations into the biological bases of the $C$. fornicata expansion and proliferation on the European Atlantic coast.

Acknowledgements. The authors thank M. Cousin, P. Gaudin, P. Rosa and A. Bargain for their technical assistance, and are grateful to O. Aumaille for her help with histology. We thank the Conseil Général de la Loire-Atlantique for the attribution of a PhD grant to A.V.

\section{LITERATURE CITED}

Arbach Leloup F, Desroy N, Le Mao P, Pauly D, Le Pape O (2008) Interactions between a natural food web, shellfish farming and exotic species: the case of the Bay of Mont Saint Michel (France). Estuar Coast Shelf Sci 76:111-120

Barillé L, Barillé AL (2003) Estimation du stock de crépidules dans la zone intertidale de la baie de Bourgneuf. Rapport de l'Université de Nantes pour la section régionale conchylicole des Pays de la Loire

Barillé L, Cognie B, Beninger PG, Decottignies P, Rincé Y (2006) Feeding responses of the gastropod Crepidula fornicata to changes in seston concentration. Mar Ecol Prog Ser 322:169-178

Beninger PG, Cannuel R, Blin JL, Pien S, Richard O (2001) Reproductive characteristics of the archaeogastropod Megathura crenulata. J Shellfish Res 20:301-307

> Beninger PG, Decottignies P, Guiheneuf F, Barillé L, Rincé Y (2007) Comparison of particle processing by two introduced suspension feeders: selection in Crepidula fornicata and Crassostrea gigas. Mar Ecol Prog Ser 334: 165-177

Beninger PG, Valdizan A, Decottignies P, Cognie B (2010a) Field reproductive dynamics of the invasive slipper limpet, Crepidula fornicata. J Exp Mar Biol Ecol 390: 179-187

Beninger PG, Valdizan A, Decottignies P, Cognie B (2010b) Corrigendum to 'Field reproductive dynamics of the invasive slipper limpet, Crepidula fornicata'. J Exp Mar Biol Ecol 390:179-187

Beukema JJ, Honkoop PJC, Dekker R (1998) Recruitment in Macoma balthica after mild and cold winters and its possible control by egg production and shrimp predation. Hydrobiologia 375/376:23-34

Blanchard M (1995) Origine et état de la population de Crepidula fornicata (Gastropoda Prosobranchia) sur le littoral français. Haliotis 24:75-86

Blanchard M (1997) Spread of the slipper limpet Crepidula fornicata (L. 1758) in Europe: current state and consequences. Sci Mar 61:109-118

Blanchard M (2009) Recent expansion of the slipper limpet population (Crepidula fornicata) in the Bay of MontSaint-Michel (Western Channel, France). Aquat Living Resour 22:11-19

Blanchard M, Ehrhold A (1999) Cartographie et évaluation du stock de crépidules (Crepidula fornicata L.) en baie du Mont Saint-Michel. Haliotis 28:11-20

Blanchard M, Thomas G (1998) Suivi des opérations de nettoyage des bancs de crépidules (Crepidula fornicata) sur le littoral de Fouras (Charente-Maritime), en mai 1995. Rapport Ifremer/DEL 98/06. Ifremer, Brest

Blanchard M, Blanchet A, Gaffet JD, Hamon D (2001) Dynamique de la population de crépidule (Crepidula fornicata) en baie de Saint-Brieuc (Manche-Ouest). Rapport Ifremer/DEL 0008. Ifremer, Brest

Blanchard M, Pechenik JA, Giudicelli E, Connan JP, Robert $\mathrm{R}$ (2008) Competition for food in the larvae of two marine molluscs, Crepidula fornicata and Crassostrea gigas. Aquat Living Resour 21:197-205

> Briarty LG (1975) Stereology: methods for quantitative light and electron microscopy. Sci Prog 62:1-32

Carlton JT (2000) Global change and biological invasions in the oceans. In: Mooney HL, Hobbs R (eds) Invasive species in a changing world. Island Press, Covelo, CA

> Chaparro OR, Saldivia CL, Pereda SV, Segura CJ, Montiel YA, Collin R (2005) The reproductive cycle and development of Crepipatella fecunda (Gastropoda: Calyptraeidae) from Southern Chile. J Mar Biol Assoc UK 85: 157-161 
Chauvaud L (1998) La coquille Saint-Jacques en rade de Brest: un modèle biologique d'étude des réponses de la faune benthique aux fluctuations de l'environnement. $\mathrm{PhD}$ thesis, Université de Bretagne Occidentale, Brest

Chipperfield PNJ (1951) The breeding of Crepidula fornicata (L.) in the river Blackwater, Essex. J Mar Biol Assoc UK 30:49-71

Cognie B, Haure J, Barillé L (2006) Spatial distribution in a temperate coastal ecosystem of the wild stock of the farmed oyster Crassostrea gigas (Thunberg). Aquaculture 259:249-259

Collin R (2003) Worldwide patterns in mode of development in calyptraeid gastropods. Mar Ecol Prog Ser 247: 103-122

Coum A (1979) La population de crepidules (Crepidula fornicata) en rade de Brest. Ecologie et dynamique. PhD thesis, Université de Bretagne Occidentale, Brest

Davis MA, Thompson K (2000) Eight ways to be a colonizer; two ways to be an invader: a proposed nomenclature scheme for invasion ecology. Bull Ecol Soc Am 81: 226-230

> Decottignies P, Beninger PG, Rincé Y, Riera P (2007a) Trophic interactions between two introduced suspension-feeders, Crepidula fornicata and Crassostrea gigas, are influenced by seasonal effects and qualitative selection capacity. J Exp Mar Biol Ecol 342:231-241

> Decottignies P, Beninger PG, Rincé Y, Robins RJ, Riera P (2007b) Exploitation of natural food sources by two sympatric, invasive suspension-feeders: Crassostrea gigas and Crepidula fornicata. Mar Ecol Prog Ser 334:179-192

> Dégremont L, Ernande B, Bédier E, Boudry P (2007) Summer mortality of hatchery-produced Pacific oyster spat (Crassostrea gigas). I. Estimation of genetic parameters for survival and growth. Aquaculture 262:41-53

> Diederich S, Nehls G, van Beusekom JEE, Reise K (2005) Introduced Pacific oysters (Crassostrea gigas) in the northern Wadden Sea: invasion accelerated by warm summers? Helgol Mar Res 59:97-106

Dupont L, Richard J, Paulet YM, Thouzeau G, Viard F (2006) Gregariousness and protandry promote reproductive insurance in the invasive gastropod Crepidula fornicata: evidence from assignment of larval paternity. Mol Ecol 15:3009-3021

Dutertre M, Beninger PG, Barillé L, Papin M, Rosa P, Barillé AL, Haure J (2009) Temperature and seston quantity and quality effects on field reproduction of farmed oysters, Crassostrea gigas, in Bourgneuf Bay, France. Aquat Living Resour 22:319-329

Dutertre M, Beninger PG, Barillé L, Papin M, Haure J (2010) Rising water temperatures, reproduction and recruitment of an invasive oyster, Crassostrea gigas, on the French Atlantic coast. Mar Environ Res 69:1-9

Ehrhold A, Blanchard M, Auffret JP, Garlan T (1998) Conséquence de la prolifération de la crépidule (Crepidula fornicata) sur l'évolution sédimentaire de la baie du Mont-Saint-Michel (Manche, France). CR Acad Sci Paris IIA 327:583-588

> Estrella Klinzing MS, Pechenik JA (2000) Evaluating whether velar lobe size indicates food limitation among larvae of the marine gastropod Crepidula fornicata. J Exp Mar Biol Ecol 252:255-279

FitzGerald A (2007) Slipper limpet utilisation and management, final report. Oyster Management Group, Port of Truro

> Gould HN (1917) Studies on sex in the hermaphrodite mollusc Crepidula plana. I. History of the sexual cycle. J Exp Zool 23:1-69

Hadfield MG, Switzer-Dunlap M (1984) Opisthobranchs. In: Tompa AS, Verdonk NH, van den Biggelaar JAM (eds) The Mollusca, Vol. 7. Reproduction. Academic Press, Orlando, FL, p 209-350

Hamon D, Blanchard M (1994) Etat de la prolifération de la crépidule (Crepidula fornicata) en baie de Saint-Brieuc. Rapport Ifremer/DEL 94/14

Haure J, Baud JP (1995) Approche de la capacité trophique dans un bassin ostréicole (baie de Bourgneuf). Rapport Interne IFREMER DVR 95-16/RA-Bouin

Hawkins SJ, Southward AJ, Genner MJ (2003) Detection of environmental change in a marine ecosystem: evidence from the Western English Channel. Sci Total Environ 310:245-256

> Hellmann JJ, Byers JE, Bierwagen BG, Dukes JS (2008) Five potential consequences of climate change for invasive species. Conserv Biol 22:534-543

Héral M, Prou J, Sauriau PG, Goulletquer P (1995) Gestion des bassins conchylicoles. Séminaire Franco-Canadien sur les maladies et problèmes environnementaux liés à l'aquaculture des mollusques, Arcachon

His E, Robert R (1985) Développement des véligères de Crassostrea gigas dans le bassin d'Arcachon. Etudes sur les mortalités larvaires. Rev Trav Inst Peche Mar 47: 63-88

> His E, Seaman MNL (1992) Effects of temporary starvation on the survival, and on subsequent feeding and growth, of oyster (Crassostrea gigas) larvae. Mar Biol 114: $277-279$

> Hollebone AL, Hay ME (2007) Propagule pressure of an invasive crab overwhelms native biotic resistance. Mar Ecol Prog Ser 342:191-196

Le Pape O, Guérault D, Désaunay Y (2004) Effect of an invasive mollusc, American slipper limpet Crepidula fornicata, on habitat suitability for juvenile common sole Solea solea in the Bay of Biscay. Mar Ecol Prog Ser 277: $107-115$

Mackin JG (1961) Mortalities of oysters. Proc Natl Shellfish Assoc 50:21-40

Mayhew TM (2000) 3D structure from thin sections: applications of stereology. Eur Microsc Anal 11:17-20

Menge BA (2000) Top-down and bottom-up community regulation in marine rocky intertidal habitats. J Exp Mar Biol Ecol 250:257-289

Morvan C, Ansell AD (1988) Stereological methods applied to reproductive cycle of Tapes rhomboides. Mar Biol 97: 355-364

Nehls G, Diederich S, Thieltges DW, Strasser M (2006) Wadden Sea mussel beds invaded by oysters and slipper limpets: competition or climate control? Helgol Mar Res 60:135-143

Pazos AJ, Román G, Acosta CP, Abad M, Sánchez J (1996) Stereological studies on the gametogenic cycle of the scallop, Pecten maximus, in suspended culture in Ria de Arousa (Galicia, NW Spain). Aquaculture 142:119-135

Rejmánek M, Richardson DM (1996) What attributes make some plant species more invasive? Ecology 77 : 1655-1661

> Richard J, Huet M, Thouzeau G, Paulet YM (2006) Reproduction of the invasive slipper limpet, Crepidula fornicata, in the Bay of Brest, France. Mar Biol 149:789-801

Rogers CE, McCarty JP (2000) Climate change and ecosystems of the Mid-Atlantic Region. Clim Res 14:235-244 
Sauriau PG, Pichocki-Seyfried C, Walker P, de Montaudouin X, Palud C, Héral M (1998) Crepidula fornicata L. (mollusque, gastéropode) en baie de Marennes-Oléron: cartographie des fonds par sonar à balayage latéral et estimation du stock. Oceanol Acta 21:353-362

Sauriau PG, Walker P, Barillé L, Barillé AL, Gruet Y, Davenne E (2006) La crépidule en baie de Bourgneuf: état du stock quarante ans après son introduction et enjeux pour l'ostréiculture de demain. In: Chaussade J, Guillaume J (eds) Pêche et aquaculture. Pour une exploitation durable des ressources vivantes de la mer et du littoral, Acte de colloque Géolittomer, Université de Nantes, Presses Universitaires de Rennes

Sax DF, Brown JH (2000) The paradox of invasion. Glob Ecol Biogeogr 9:363-371

Schneider SH (2001) What is 'dangerous' climate change? Nature 411:17-19

Seitz RD, Lipcius RN (2001) Variation in top-down and bottom-up control of marine bivalves at differing spatial scales. ICES J Mar Sci 58:689-699

Severns P (2007) Does standing water and predator presence structure a wetland terrestrial mollusc community? Wetlands 27:964-971

Soulas M, Blanchard M, Hamon D, Halary C (2000) Projet d'exploitation de la crépidule en Bretagne Nord en vue de la restauration des fonds colonisés. Restauration des écosystèmes côtiers. Ifremer Actes Colloq 29: 230-242

Stachowicz JJ, Terwin JR, Whitlatch RB, Osman RW (2002)

Editorial responsibility: Inna Sokolova, Charlotte, North Carolina, USA
Linking climate change and biological invasions: ocean warming facilitates non-indigenous species invasions. Proc Nat Acad Sci 99:15497-15500

ter Hofstede R, Hiddink JG, Rijnsdorp AD (2010) Regional warming changes fish species richness in the eastern North Atlantic Ocean. Mar Ecol Prog Ser 414:1-9

- Thieltges DW, Strasser M, van Beusekom JEE, Reise K (2004) Too cold to prosper: winter mortality prevents population increase of the introduced American slipper limpet Crepidula fornicata in Northern Europe. J Exp Mar Biol Ecol 311:375-391

> Valdizan A, Beninger PG, Cognie B, Decottignies P (2009) External fertilization and excapsular development in Crepidula fornicata: evaluating the risk of invasion control by dredging, crushing, and on-site rejection. Aquat Living Resour 22:21-28

> Velasco LA, Navarro JM (2005) Feeding physiology of two bivalves under laboratory and field conditions in response to variable food concentrations. Mar Ecol Prog Ser 291:115-124

Weibel ER, Kistler GS, Scherle WF (1966) Practical stereological methods for morphometric cytology. J Cell Biol 30:23-38

Werner B (1948) Die amerikanische Pantoffelschnecke Crepidula fornicata L. im nordfriesischen Wattenmeer. Zool Jahrb 77:449-488

> Zhao B, Qiu JW, Qian PY (2003) Effects of food availability on larval development in the slipper limpet Crepidula onyx (Sowerby). J Exp Mar Biol Ecol 294:219-233

Submitted: November 8, 2010; Accepted: June 8, 2011 Proofs received from author(s): September 22, 2011 